\title{
¿Qué nos dejó la movilización de los pingüinos?
}

\author{
Juan Eduardo García-Huidobro S. ${ }^{1}$
}

Estamos a tres años de la manifestación masiva de los y las estudiantes secundarios que fue calificada como "movimiento pingüino." Buen lapso para balances.

El movimiento pingüino va a quedar consignado en la historia sociopolítica de Chile por muchos motivos. Fue la primera movilización social masiva y de carácter nacional desde la recuperación de la democracia. Con razón estos jóvenes se autodenominaron "hijos e hijas de la democracia," para subrayar su pertenencia a una nueva generación que no conoció la dictadura y que reivindica, sin temor al conflicto, sus derechos. ${ }^{2}$ Es un caso raro de movimiento social en el cual los actores principales, los portadores de su contenido y los conductores de sus acciones, fueron las organizaciones de estudiantes secundarios. Se trató, además, de una movilización de profundo sentido político cuando era común afirmar la desafección de los jóvenes a la política. Su organización también incorporó novedades: primó una estructura muy horizontal, que funcionó gracias a la plena incorporación de las nuevas tecnologías NTIS (celulares, internet...), para constituir y conducir el movimiento.

Pero la movilización pingüina no sólo incorpora novedad también aporta valor a la política en general y al campo más específico de la política educativa.

Las protestas de los jóvenes no dejaron inerte a la comunidad; constituyeron más bien una ocasión para que la sociedad civil pudiese apoyar, expresar y hacer presente que las demandas estudiantiles eran justas y eran también demandas de toda la ciudadanía. Estas manifestaciones, escasas en Chile debido a la particular forma que tuvo entre nosotros el término de la dictadura, enriquecen la democracia, ya que permiten que el sistema político conozca y pueda procesar mejor las visiones y anhelos de la ciudadanía. 
En el plano educativo los pingüinos movieron el centro de gravedad de la política. La educación chilena venía, desde los 60, aumentando persistentemente la escolaridad. La mayoría del país apreciaba que la situación educacional experimentaba una creciente mejoría; los hijos e hijas lograban más educación formal que sus padres; aun en los grupos más pobres todos finalizan la educación básica y un número cada vez mayor la educación media. Paradojalmente la revolución pingüina se apoya en esos logros para dar un paso más y poner al centro la demanda por igualdad. María Jesús Sanhueza diagnostica una nueva crisis educacional consistente en "que la desigualdad que existe en la educación chilena es abismante." La mayoría termina su educación media, pero "los alumnos de colegios municipales obtienen resultados muy inferiores que los de colegios privados." ${ }^{3}$ Las mismas ideas son expresadas por otra de los líderes: "es cuestión de mirar alrededor y constatar que el sistema económico neoliberal que nos rige permite sólo a los que tienen dinero acceder a una educación de mejor calidad, a colegios mejores equipados." ${ }^{4}$

¿Cómo evaluar los avances de estos tres años?

Desde el punto de vista de una mejor sintonía entre la sociedad civil y la sociedad política, el Consejo Asesor Presidencial convocado por la Presidenta fue una experiencia positiva. En él se expresó y argumentó las distintas visiones que conviven sobre lo que la educación debe ser. Sin embargo esta "expresividad," que debería haber permitido un debate parlamentario más rico, se desperdició y se llegó a un "acuerdo" negociado entre el Ejecutivo y la Alianza, sin dar lugar a un proceso real de deliberación.

En política educativa la discusión dio un gran salto. El movimiento pingüino obligó a discutir temas de nuestro "orden educativo," instalados en dictadura, que no se habían cuestionado durante los anteriores gobiernos de la Concertación. Así, se puso en examen el que se haya asumido un criterio mercantil para asignar el bien "educación," lo que implica según muchos una negación de la igualdad educativa como valor y un menoscabo a la ciudadanía. También se levantó la pregunta sobre la capacidad de la municipalización para organizar y administrar la educación pública, sin reproducir en ella la profunda heterogeneidad y desnivel de los municipios. Por último, se tomó conciencia de la necesidad de equilibrar la libertad de enseñanza y la diversidad 
en la educación, con el contrapeso de un aparato estatal capaz de un efectivo control del sistema y de dar apoyo técnico a los más débiles.

Estos temas guardan relación con las tres leyes en discusión en el Parlamento. Leyes que, a mi juicio, se quedan cortas en los tres puntos mencionados. La Ley General de Educación no pone en duda ni atempera suficientemente la distribución de la educación a través del mercado. La Ley de Fortalecimiento de la Educación Pública mantiene en los municipios (y en los alcaldes) la responsabilidad de mejorar la educación pública. La Ley sobre el Sistema Nacional de Aseguramiento de la Calidad, no toca de igual modo a todos los tipos de establecimientos (¡no es en realidad nacional!), ni genera una institucionalidad estatal tecnificada y fuerte para controlar y entregar apoyo.

\section{Notas}

1 Profesor de la Universidad Alberto Hurtado. Ex presidente del Consejo Asesor para la calidad de la educación.

2 Valenzuela, César. 'Que la educación retorne al Estado', entrevista al vocero secundario César Valenzuela.2006. En: http://www.archivochile.com/edu/secund.html

3 Sanhueza, María Jesús. Entrevista a María Jesús Sanhueza, vocera de la ACES, 2006. En: http://www.archivochile.com/edu/secund.html

4 Huerta, María. Entrevista María Huerta, dirigenta estudiantil: el derecho a la educación es lo primero, Programa Interdisciplinario de Investigación en Educación, PIIE, 2006. En: http://www.piie.cl/ entrevistas/maria_huerta.htm 